\title{
Investigating key biological parameters of Nile tilapia (Oreochromis niloticus L.) in a large Asian reservoir to better develop sustainable fisheries
}

\section{Étude des principaux traits biologiques du Tilapia du Nil (Oreochromis niloticus L.) d'un grand réservoir asiatique dans la perspective d'améliorer le développement de la pêche durable}

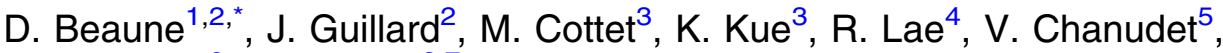 \\ S. Descloux ${ }^{6}$, A. Tessier ${ }^{2,7}$
}

1 Biogéosciences, UMR 6282 CNRS, Université Bourgogne Franche-Comté, 6, Boulevard Gabriel, 21000 Dijon, France david.beaune@gmail.com

2 UMR CARRTEL. (INRA-USMB), Centre Alpin de Recherche sur les Réseaux Trophiques et les Ecosystèmes Limniques, 75, bis Av. de Corzent, 74203 Thonon les Bains Cedex, France

3 Nam Theun 2 Power Company Limited (NTPC), Environment \& Social Division, Environment Department, Gnommalath Office, PO Box 5862, Vientiane, Laos

4 IRD, Lemar UMR 6539, IUEM Technopôle Brest-Iroise, rue Dumont d'Urville, 29280 Plouzané, France

${ }^{5}$ EDF, Hydro Engineering Center, Savoie Technolac, 73370 Le Bourget du Lac, France

${ }^{6}$ EDF-Dismantling and Environmental Services Division, 154, avenue Thiers, 69006 Lyon, France

7 MAREPOLIS, Université de Perpignan, 58, avenue Paul Allduy, 66860 Perpignan, France

\begin{abstract}
The Nile tilapia (Oreochromis niloticus) was introduced in Southeast Asia, such as in Thailand, in the mid-1960s for aquaculture purposes (Pullin et al., 1997; De Silva et al., 2004). The species was later promoted for aquaculture development in the early 1990s in Lao PDR (Garaway et al., 2000). In Lao People's Democratic Republic (PDR), like in other countries, this exotic species is well established due to its self-reproduction (De Silva et al., 2004; CABI, 2018) facilitated by its particular life history traits and plasticity (Ishikawa et al., 2013). The species was then suspected to be introduced in the seventies in Laos and subsequently in the Nam Theun watershed where the NT2 Reservoir was impounded in 2008. Population parameters of this alien fish were investigated using the FiSAT II software with the most popular methods of bioparameters assessment to check their interchangeability within a same stock and the same year 2016. The length-at-age data analysis (using otoliths analysis, $\mathrm{N}=258$ ) gave slightly different results with the length frequency distribution analysis of fish landings (11820 individuals). Furthermore, experimental fishing data provided irrelevant parameters due to insufficient representativeness of the sample size. The growth parameter $K$ was estimated to be 0.23 year $^{-1}$, with asymptotic length
\end{abstract}


$L_{\infty}=52.5 \mathrm{~cm}$ based on the length frequency distribution analysis with the fish landing data. According to these landing data, the total, natural and fishing mortality were $Z=1.41$ year $^{-1}$, $M=0.30$ year $^{-1}$ and $F=1.11$ year $^{-1}$. The exploitation rate $E=0.79$ is over the $E_{\max }=0.594$ obtained by relative yield and biomass per recruit. This estimated stock of 165 tons (more than 700000 tilapias) was characterized by high mortality (no population growth). These results showed that the population is overfished with too many juveniles caught $\left(L_{50}=210.4 \mathrm{~mm} ; 50 \%\right.$ mature stages at $\left.295 \mathrm{~mm}\right)$. To maximize the yield per recruit, increase the biomass and sustain this fishery, enlarging the gillnet mesh size of the gill-net is recommended. This example highlights the variability of the parameters calculated from different methods and thus weaken worldwide and even inter-site comparisons. Despite this issue, the Growth Performances Indices $\left(\varphi^{\prime}\right)$ gathered into the literature can serve as baseline and confirmed the wide phenotypic plasticity of the species due to environmental factors. Analyses revealed difference between fast growing domesticated fish rose for aquaculture with $\varphi^{\prime}$ higher to the tilapia growing in natural and challenging environments.

Key words - cichlidae, FiSAT, fishing management, growth rate, otolith, reservoir

Résumé - Le Tilapia du Nil (Oreochromis niloticus) a été introduit en Asie du sud-ouest, notamment en Thaïlande, dans le milieu des années 1960, à des fins d'aquaculture. Ce n'est que dans les années 1990 que cette espèce a été introduite au Laos pour ce même objectif. Cette espèce exotique, de par sa capacité de reproduction naturelle induite par ses traits d'histoire de vie et sa plasticité phénotypique, est bien établie au Laos, ainsi que dans d'autres pays asiatiques. Cette espèce présente dans le bassin versant de Nam Theun aurait ainsi colonisé le réservoir de Nam Theun 2 (NT2) lors de sa mise en eau en 2008, avec également des actions sporadiques d'empoissonnements. Les paramètres de la population du réservoir de NT2 ont été étudiés en recourant à FiSATII avec les méthodes d'évaluation des bio-paramètres les plus populaires pour vérifier leur interchangeabilité dans un même stock et pour une même année (2016). L'analyse de la relation taille-âge, via l'analyse de 258 otolithes, a donné des résultats légèrement différents de l'analyse des fréquences de tailles issues des débarquements réalisées sur 11820 individus. Les données issues des pêches expérimentales ont quant-à-elles fournis des résultats non pertinents de par le faible effectif des échantillons. La croissance $(k)$ a été estimée à $0,23 \mathrm{~cm} \mathrm{an}^{-1}$ avec une longueur asymptotique $\left(L_{\infty}\right)$ de $52,5 \mathrm{~cm}$. Selon les données de débarquements la mortalité totale, naturelle et par pêche étaient respectivement de $1,41,0,30$ et $1,11 \mathrm{an}^{-1}$. Le taux d'exploitation $(0,79)$ était supérieur au taux d'exploitation maximal $(0,594)$ obtenu par le rendement relatif et la biomasse par recrue. Le stock estimé de 165 tonnes (plus de 700000 individus) était caractérisé par une mortalité élevée. Ces résultats ont montré que la population était surexploitée et que de nombreux juvéniles étaient capturés $\left(L_{50}=210,4 \mathrm{~mm} ; 50 \%\right.$ mature à $295 \mathrm{~mm}$ ). Pour maximiser le rendement par recrue, augmenter la biomasse, et soutenir la pêche, il est recommandé d'augmenter la taille des mailles des filets de pêche. Cet exemple met en évidence la variabilité des paramètres calculés à partir de différentes méthodes ce qui sous-entend que les comparaisons avec les autres populations dans le monde, mais également inter-sites sont difficiles. Toutefois les indices de performance de croissance $\left(\varphi^{\prime}\right)$ relevés dans la littérature peuvent servir de référentiel et confirmer la 
grande plasticité phénotypique de cette espèce selon les facteurs environnementaux. Les analyses ont révélé que les populations aquacoles présentaient une croissance plus rapide que celle des populations vivant dans les environnements naturels contraignants.

Mots-clés - cichlidae, FiSAT, gestion des pêcheries, taux de croissance, otolithe, réservoir

\section{Introduction}

Tilapia (including all species) is the second most important group of farmed fish after carps, and the most widely grown of any farmed fish in the world (FAO, 2009). The most desirable Nile tilapia (Oreochromis niloticus (Linnaeus, 1758); [Perciformes: Cichlidae]), because of its advantageous biological traits (feeding habits and fast growth) was deliberately introduced in tropical countries during the 1960 s up to the 1980 s, promoted by international aid and development agencies (FAO, 2009). Consequently this alien fish originating from East Africa, colonized natural freshwater systems and is currently well established in 75 countries (Africa: 16, Asia: 25, Europe: 6, North America: 18, Oceania: 3, South America: 7; (FishBase, 2018).

This species is invasive, and became the dominant species in terms of density and biomass in various tropical colonized areas (Zambrano et al., 2006; Weyl, 2008; Zengeya et al., 2013). In an ecosystem, Nile tilapia population can affect the nutrient cycling (e.g. indirectly contribute to the occurrence of cyanobacteria blooms and water eutrophication (Figueredo and Giani, 2005), trigger the extinction of native and endemic species (Canonico et al., 2005; Casal, 2006) and probably affectotherecological processes (Canonico et al., 2005; Cucherousset and Olden, 2011). So in freshwater tropical colonized areas, the Nile tilapia is now the main fishing resource of protein for human population, and eventually provides food security (FAO, 2009). An adequate fishing management is then required to avoid overexploitation and preserve sustainable fisheries. In this context, knowledge on the key biological parameters (growth, length, mortality) has to be investigated to better understand the local population biology and then to better develop sustainable fisheries.

One of the most popular methods for estimating biological parameters is to use length frequency data that are fast and cheap to gather (Sparre, 1998) or the length-at-age analysis based on scales, opercular bones or otoliths age readings. Both analyses can be performed with the FAO-ICLARM (Fish Center) Stock Assessment Tool (FiSAT II) which is broadly used for tropical fish stock assessment (>1700 citations) and contains both routines for the analyses (Gayanilo et al., 2005). In this paper the widely used 'length frequency distribution analysis' was compared to the parameters obtained with 'analysis of length-at-age' from fish aged with otoliths using FiSAT II. These 
Table 1. Biological parameters from three methods (2 LFA and 1 otoliths) of the stock $O$. niloticus stock using FiSATII. The parameters are: predicted asymptotic length $\left(L_{\infty}\right.$, Standard (SL) and Total Length $(T L)$ ), growth coefficient $K$, growth performance index $\varphi^{\prime}$, and hypothetical length at which age is zero to, the exploitation rate $E$, total coefficient of mortality $Z$, natural mortality $M$, and fishing mortality $F$. ID = insufficient data.

Tableau 1. Paramètres biologiques pour trois méthode (2 LFA et 1 otolithe) du stock d'O. niloticus via FiSATII. Les paramètres sont: longueur asymptotique prédite $\left(L_{\infty}\right.$, standard $(\mathrm{SL})$ et longueur totale $(T L)$ ), coefficient de croissance $K$, indice de performance de croissance $\varphi^{\prime}$ et longueur hypothétique pour laquelle l'âge est égal à zéro $t 0$, le taux d'exploitation $E$, coefficient total de mortalité $Z$, mortalité naturelle $M$ et mortalité par pêche $F$. ID= données insuffisantes.

\begin{tabular}{|c|c|c|c|c|c|c|c|}
\hline Methods & $\mathrm{SL} \infty(\mathrm{cm})$ & $\mathrm{TL} \infty(\mathrm{cm})$ & $\mathrm{K}\left(\right.$ year $\left.^{-1}\right)$ & $\left(\varphi^{\prime}\right)$ & $t_{0}$ (years) & $\mathrm{E}$ & $\mathrm{Z} / \mathrm{M} / \mathrm{F}\left(\right.$ year $\left.^{-1}\right)$ \\
\hline $\begin{array}{l}\text { Analysis of Length-at-age } \\
\text { data (all fish) }(\mathrm{N}=258, \\
\text { incl. } 58 \text { not sexed) }\end{array}$ & 45.47 & 55.61 & 0.14 & 2.636 & -0.28 & & \\
\hline $\begin{array}{l}\text { Analysis of Length-at-age } \\
\text { data (o'Males) (93) }\end{array}$ & 43.81 & 53.58 & 0.14 & 2.604 & -0.47 & & \\
\hline $\begin{array}{l}\text { Analysis of Length-at-age } \\
\text { data (oFemales) (107) }\end{array}$ & 31.75 & 38.83 & 0.23 & 2.540 & -1.17 & & \\
\hline $\begin{array}{l}\text { Length Frequency } \\
\text { Distribution Analysis } \\
\text { from fish landings (11 820) }\end{array}$ & 52.5 & 64.21 & 0.23 & 2.977 & & 0.79 & $1.41 / 0.30 / 1.11$ \\
\hline $\begin{array}{l}\text { Length Frequency Distribution } \\
\text { Analysis from experimental } \\
\text { fishing (95) }\end{array}$ & 24.1 & 29.47 & 0.14 & 2.085 & & ID & ID \\
\hline
\end{tabular}

three methods are the most common in the abundant $\mathrm{O}$. niloticus literature (see ref. of Tab. 1).

The study case population is from Lao People's Democratic Republic, in the second-largest reservoir in the country, the Nam Theun 2 (NT2). This reservoir was impounded in April 2008 and after a classical trophic upsurge, the system seems to have reached ecological stabilization in 2011 (Cottet et al., 2016). The Nile tilapia represents the major part of the catch by the local fishery and is of significant economic importance $(52 \%$ of relative biomass contribution of total catch, (Cottet and Visser, 2017). Biological parameters of this fish species constitute essential data to assess population dynamic and the exploitation level for fisheries management. This is especially needed in this oligotrophic reservoir with relatively low fish density and where the fishing activity settled from less than ten years.

Objectives of this study are to provide: (1) First analyses of detailed data on a tilapia population in Lao PDR; (2) comparison of popular bio parameter assessment methods in a context of improving fisheries management and furthermore; (3) comparison of other world tilapia population data.

\section{Materials and methods}

\subsection{Study site}

The Nam Theun 2 (NT2) hydropower reservoir is located in the center of Lao PDR (Khammouane Province) on two sub catchments of the Mekong River (Descloux et al., 2016). The reservoir 
impoundment started in April 2008 and commercial operation began in April 2010. The reservoir has a total volume of 3.9 billion $\mathrm{m}^{3}$, covering an area of $489 \mathrm{~km}^{2}$ at full supply level and $86 \mathrm{~km}^{2}$ at the (theoretical) minimum operating level. The project design led to divert the waters from the Nam Theun watershed to the XeBangfai watershed (Descloux et al., 2016). A total of 33 fish species belonging to 10 families were identified in the reservoir (between 2008 and 2013) (Cottet et al., 2016). Cyprinidae dominated fish populations with a total of 24 species. A total number of 2182 households living was estimated in 16 hamlets along the reservoir in $2014 ; 85 \%$ of them are active in fishing activities with a fluctuating average of $\left[2.5-8 \mathrm{~kg}\right.$ HouseHold $^{-1}$ day $^{-1}$ ] (Cottet and Visser, 2017).

\subsection{Fish sampling}

Data were collected with two sampling methods: fish landing and scientific experimental fishing.

Each of the three villages of Done, Nongbouakam and Nakai Tai (stars of the Fig. 1), was sampled for five consecutive days per month between January to December 2016. Each day, the first ten fishermen reaching the landing site were individually interviewed about their fishing gears (type, mesh size, number of hooks, etc.) and their catches regarding O. niloticus were all recorded. For each fisherman, when the number of individuals was higher than 30 , only 30 individuals were randomly selected to be further measured and weighted. A total of 11820 individuals were recorded for the year, representing about $48 \%$ of the yield (mixed techniques used from 246 different fishers, including gillnets with mesh size ranging between 10 and $200 \mathrm{~mm}$, hook lines and set lines).

Second data set was obtained from scientific experimental fishing at five stations (Fig. 1). A total of 95 fish were caught from these experimental monthly gillnet surveys in 2016 (gillnets: $25 \times 2 \mathrm{~m}$; mesh size: $10,15,20,25$, $30,35,40,50,60$ and $70 \mathrm{~mm}$ ) representing 24 nights of sampling effort. The gillnet mesh sizes were selected to capture a wide range of fish.

\subsection{Ethical statement}

The experimental fishing were performed by the Nam Theun 2 Power Company who has the national authorization for fish population monitoring and research in rivers and reservoir by the Lao Government namely the Ministry of Agriculture and Forestry representative on Province level and the Nakai Natural Protected area (namely the Watershed Management Protection Secretariat). This authorization includes the traditional fishing method with gillnets used in this study. This authorization started in 2008 to allow fish population monitoring in the dam area and as an obligation of monitoring between the company and the Government of Laos in the Concession Agreement-Environment and Biodiversity Obligation. The sampling did not catch endangered or protected fish species, the targeted species are exploited species and the experimental fishing followed established guidelines for treatment of animals in research. 


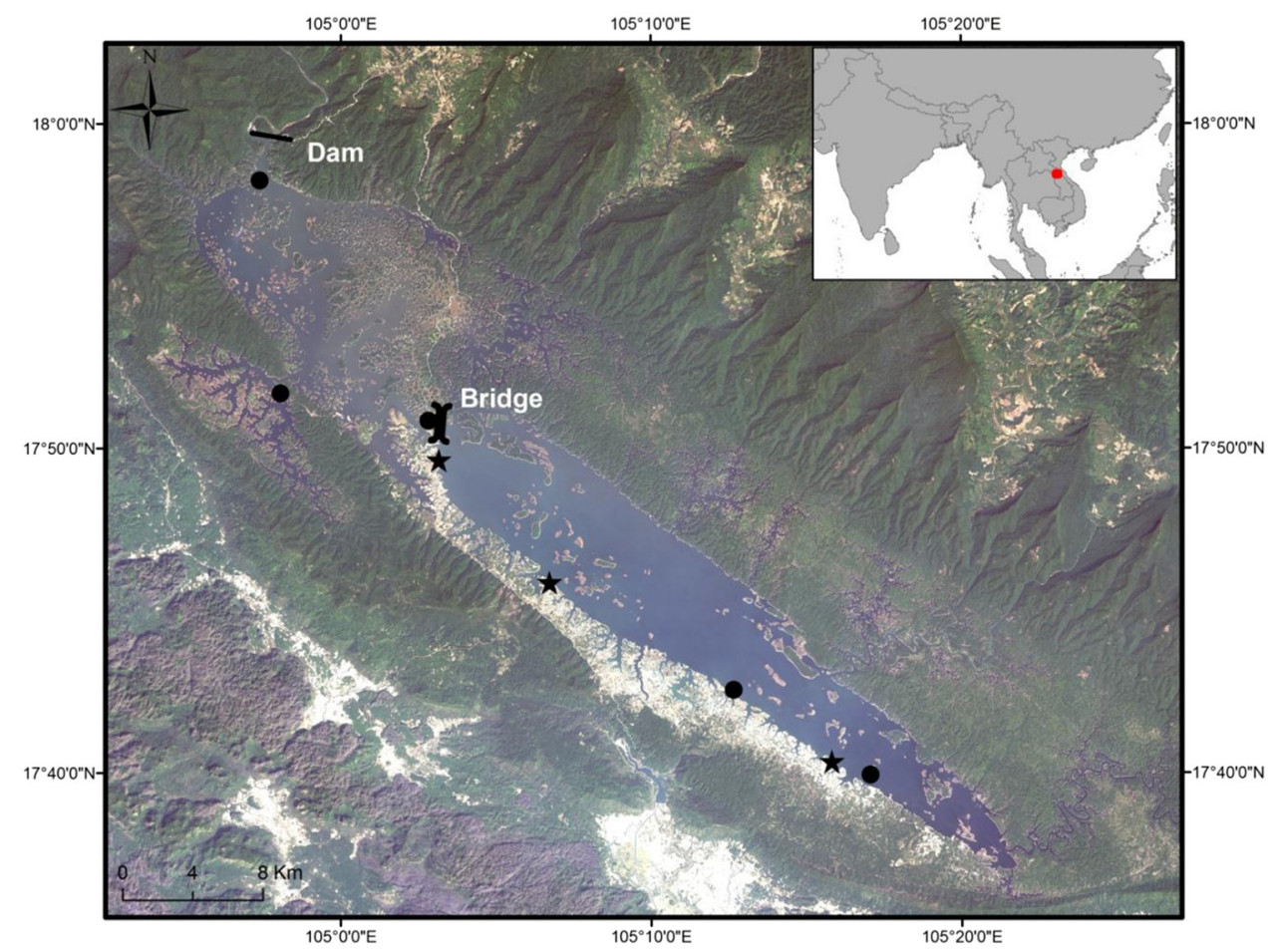

Fig. 1. Map of the Nam Theun 2 Reservoir in Lao PDR at its higher level and localization of sampling site by experimental gillnet fishing (black dots) and the three sampled villages by fish landings (black stars).

Fig. 1. Carte du réservoir de Nam Theun 2 au Laos à son niveau maximal de remplissage et localisation des sites d'échantillonnage par pêche expérimentale (point noir) et des villages échantillonnés par le suivi des débarquements (étoile noire).

\subsection{Biological parameters}

For both sampling methods, the standard length $(S L \pm 1 \mathrm{~mm})$ and sex of each individual were recorded. Lengths were assigned to a class size of $10 \mathrm{~mm}$.

For the analysis of length-at-age, 258 Nile tilapia individuals were randomly selected from the fish landing in 2016, and from experimental fishing. Age was determined for each individual by counting annuli on the otoliths after validation of only one annulus formation per year (Tessier et al., 2017).
For the length frequency distribution analysis, data were first obtained from fish landing.

This analysis was performed with the Electronic Length Frequency Analysis (ELEFAN I) package incorporated in FiSAT II (Sparre, 1998; Gayanilo et al., 2005). ELEFAN is a very popular method frequently used in length frequency analysis of fish. It is a nonparametric, ad hoc method, and not dependent on cohort distributions directly. Lengths of each cohort are fixed such as in the von Bertalanffy growth model (1) which makes a strong 
assumption about growth, with the formula containing the asymptotic length $(L \infty)$ or the length the species can reach, the length $(L)$ at age class time $t$, the instantaneous growth coefficient $K$ and $t 0$ the point at which the von Bertalanffy curve intersects the $x$-axis:

$$
L t=L \infty\left(1-\exp ^{(-K(\mathrm{t}-\mathrm{t} 0)}\right) .
$$

The growth performance index $\left(\varphi^{\prime}\right)$, also found as $\Phi^{\prime}$ or $\varnothing^{\prime}$ in literature, is quantified using (Pauly and Munro, 1984) formula (2):

$$
\varphi^{\prime}=\log _{10} K+2 \log _{10} L \infty,
$$

with $L \infty$ expressed in Total Length (TL) here, as required in FiSAT II routine for comparability. Total mortality coefficient $(Z)$ is estimated from fish landings and experimental fishing using the lengthconverted catch curve method (Pauly, 1983) from the pooled length frequency data for the study period (the curve $=Z$ ). The natural mortality coefficient $(M)$ is estimated following Pauly's empirical formula (Pauly, 1980) (3):

$$
\begin{aligned}
\ln (M) & =-0.0152-0.279 \ln (L \infty) \\
& +0.6543 \ln (K)+0.463 \ln \left(\mathrm{T}^{\circ} \mathrm{C}\right),
\end{aligned}
$$

linking natural mortality with the von Bertalanffy parameters ( $K$ and $L \infty)$ and the mean annual temperature $\left(T^{\circ} \mathrm{C}\right)$ of the surface water in which the fish live (in this case) temperatures of the surface water were recorded for several stations every month by the Environment and Social Division, Environment Department of the Nam Theun 2 Power Company Limited which is the manager of the reservoir. The average surface temperature for 2016 was $26.5^{\circ} \mathrm{C}$. Fishing mortality $(F)$ was computed from the relationship $F=Z-M$, while the exploitation rate $(E)$ was calculated from (4):

$$
E=\frac{F}{Z}=\frac{F}{(F+M)} .
$$

The recruitment model with pulse was obtained by projecting the length frequency data back on the time axis using the growth parameters determined above. The normal distribution of the recruitment model was determined by NORMSEP (Gayanilo et al., 2005).

\subsection{Virtual population analysis, fish stock and fishing management}

The probabilities of capture are inferred from the length-converted catch curves, by backward extrapolation of the catch curve and comparison of the numbers actually caught with those that "ought" to have been caught (Sparre, 1998; Gayanilo et al., 2005). The standard length for which 25, 50 and $75 \%$ of the fish are caught $\left(L_{25}, L_{50}\right.$, $L_{75}$ ) were estimated with running averages technique (Pauly, 1983) with FiSATII. A virtual population analysis (VPA) estimated the tilapia stock (biomass, population size $(\mathrm{N})$ ) at the NT2 Reservoir from fish landing data and parameters determined above. For the biomass estimation, the standard length-weight relationship for these Tilapia was calculated with (5):

$$
\log _{10} W=\log _{10} a+b \log _{10} L,
$$


where $\quad b=[3.23323-3.27171]$ and $a=[0.01699-0.01897] \quad\left(I_{95}\right), N=653$ fish from 6 to $410 \mathrm{~mm}$; length-weight relationship $R^{2}=0.9943$; (unpub. species results, method based on (Tessier et al., 2017)).

Based on the previous parameters and frequencies, FiSATII can still be used to predict the relative yield and biomass per recruit $\left(Y^{\prime} / R\right.$ and $\left.B^{\prime} / R\right)$ of $O$. niloticus to the fisheries. Plots of $Y^{\prime} / R$ vs. $E(=F / Z)$ and of $B^{\prime} / R$ vs. $E$, from which $E_{\max }$ (exploitation rate which produces maximum yield), $E_{0.1}$ (exploitation rate at which the marginal increase of relative yield-per-recruit is $10 \%$ of its unexploited biomass $E=0$ ) and $E_{0.5}$ (value of $E$ under which the stock has been reduced to $50 \%$ of its unexploited biomass) are also computed through the first derivative of the Beverton and Holt function (Beverton and Holt, 1966). These are used as target reference points for best fishing management.

Yield contours are plotted to assess the impact on yield of changes in exploitation rate $E$ and critical length ratio $L_{c} / L_{\infty}$. (LC being mean length of fish at first capture, $=L_{50}$ ). . The resulting isopleths map can be used to determine the best $E$ and $L c / L \infty$ to reach the maximal $Y^{\prime} / R$ and $B^{\prime} / R$ at the current situation.

Additional length is calculated as additional help fishing management decision: $L_{\text {opt }}$ which is the length where the biomass of an unfished cohort reaches its maximum (Beverton, 1992; Froese et al., 2008) (6):

$$
L_{\text {opt }}=L_{\infty} \frac{3}{3+\left(\frac{M}{K}\right)} .
$$

The standard length at which $50 \%$ of Nile tilapias are still immature and the other half starts to be mature was estimated based on the 258 fish measured above ( $S L \pm 1 \mathrm{~mm})$. These lengths were compared with $L c$. Maturity stage was described by a 1 or a 0 observing: (1) gonads presence ( + ovule for females $=$ stage 3 for this species) and (+ semen dripping from the gonads for males $=$ stage 4 ) or (0) no visible gonads.

A logistic regression was fitted in $R$ with the general linear model procedure using the fishR package. The Thompson and Bell yield and stock prediction routine in FiSAT II was used for prediction of harvested fish and biomass changes with an example of management recommendation (Thompson and Bell, 1934). This model combines features of Beverton and Holt's $Y^{\prime} / R$ model with those of VPA, which it inverts. The current fishing rate and $L_{c}$ were compared with increased $L_{c}$ and $L_{o p t}$ determined bellow only, without modification of $F$.

\subsection{Lao reservoir and worldwide $\varphi^{\prime}$ comparison}

Biological parameters from other tilapia populations of various ecological contexts (natural and farmed) have been gathered from available literature and analysed for comparisons with the NT2 tilapia population. According to (Moreau et al., 1986), the growth performance index $(\varphi$ ') values should be equal or roughly similar between different stocks in a normal distribution. We tested this assumption and hypothesised that this pan-tropical species showed a phenotypic plasticity with a wide spectrum of $\varphi^{\prime}$ 
irrespectively to continents or water systems, but fish from aquaculture raised in optimal settings should have a better $\varphi^{\prime}$ than in natural and challenging conditions (Pauly et al., 1988). We also checked (with objective (2)) if biological parameter variability could also be due to variability in methodology.

To test the normal distribution of worldwide O. niloticus $\varphi$ ', Shapiro-Wilk and graphical tests were performed on Table 1 values. These data were collected from published works based on bibliographic search, with the keywords "Oreochromis + niloticus" in Web of Science (from 1970 to August 2018) and from relevant works found in the references sections. Continental effects on populations, and other potential effects such as hydrosystems (reservoir, lake, cage, pond, etc.) were tested with analysis of variances, Kruskal-Wallis and Pairwise comparisons using Wilcoxon rank sum tests. These tests were realized with $R$ software $(R$ Development Core Team, 2011). Only the average was considered for cases with multiple values at a same site.

Because the reported fish lengths were standard length (SL) or total length (TL) in the literature, we established the $O$. niloticus TL/SL relationship based on 322 fish caught and measured into the NT2 Reservoir (the 258 aged Nile tilapia individuals randomly selected from the fish landing in $2016+64$ not aged). The relationship was $\left(R^{2}=0.99\right): T L=1.223$ $\times \mathrm{SL}$, and it allowed recalculate comparable growth performance indices $\left(\varphi^{\prime}\right)$.

\section{Results}

\subsection{Biological parameters}

At the NT2 Reservoir, age of the 258 fish given by otolith readings ranged from 0 to
8 years old (Max. $q=8$ years, Max. $\delta^{\dagger}=7$ years), with standard length ranging from 31 to $360 \mathrm{~mm}$. The $L \infty$ mean $( \pm S E)$ was $454.7 \pm 123.8 \mathrm{~mm}(\%=317.5 \pm 124.1 \mathrm{~mm}$; $\left.\mathrm{O}^{\dagger}=438.1 \pm 284.9 \mathrm{~mm}\right)$. The mean growth coefficient $(K)$ was $0.14 \pm 0.06 \mathrm{yr}^{-1}$ $\left(q=0.23 \pm 0.34 \mathrm{yr}^{-1} ; \mathrm{o}^{-1}=0.14 \pm 0.17 \mathrm{yr}^{-1}\right)$ and the growth performance indices $(\varphi$ ') was $2.636\left(q=2.540 ; o^{\star}=2.604 ;\right.$ Tab. 1$)$. For length frequency distribution analyses, data ranged from 65 to $495 \mathrm{~mm}$ for fish landing and from 37 to $303 \mathrm{~mm}$ for experimental fishing. The $L_{\infty}$ means, $(K)$ and $\left(\varphi^{\prime}\right)$ were respectively (no SE available) $L_{\infty}=525.0 \mathrm{~mm}, \quad(K)=0.230 \mathrm{yr}^{-1}$, $\left(\varphi^{\prime}\right)=2.977$ for fish landing and $L \infty=241.5$ $\mathrm{mm},(K)=0.140 \mathrm{yr}^{-1},\left(\right.$ Tab. 2). $\left(\varphi^{\prime}\right)=2.085$ for experimental fishing.

The mean estimated total mortality coefficient $(Z)$ was $1.41 \pm 0.23$ year $^{-1}$, $\mathrm{IC}_{95}=$ [1.33-1.50]; natural mortality coefficient $(M)=0.30$ year $^{-1}\left(\right.$ at $\left.26.5^{\circ} \mathrm{C}\right)$ fishing mortality coefficient $(F)=1.11$ year $^{-1}$ and exploitation rate $(E)=0.79$ from the fish landing data (Fig. 2 left). The experimental fishing did not allow relevant results (e.g. relative age of fish at 22 years old, $Z<M$, etc.).

The recruitment model showed continuous recruitment of $O$. niloticus all along the year with slight peaks in January and in March-April (11.0 and $18.4 \%$, respectively).

\subsection{Virtual population analysis and fishing management}

With current Fish mortality, $F$ of 1.11 , the optimal $F_{\text {opt }}$ should be $0.5 \mathrm{M}=0.15$ and the limit $F_{\text {lim }}$ should be $1 / 3 M=0.10$. The mean length at the entry into the fishery at $L_{25}, L_{50}$, and $L_{75}$ were 202.43 , 210.38 and $219.28 \mathrm{~mm}$ respectively 


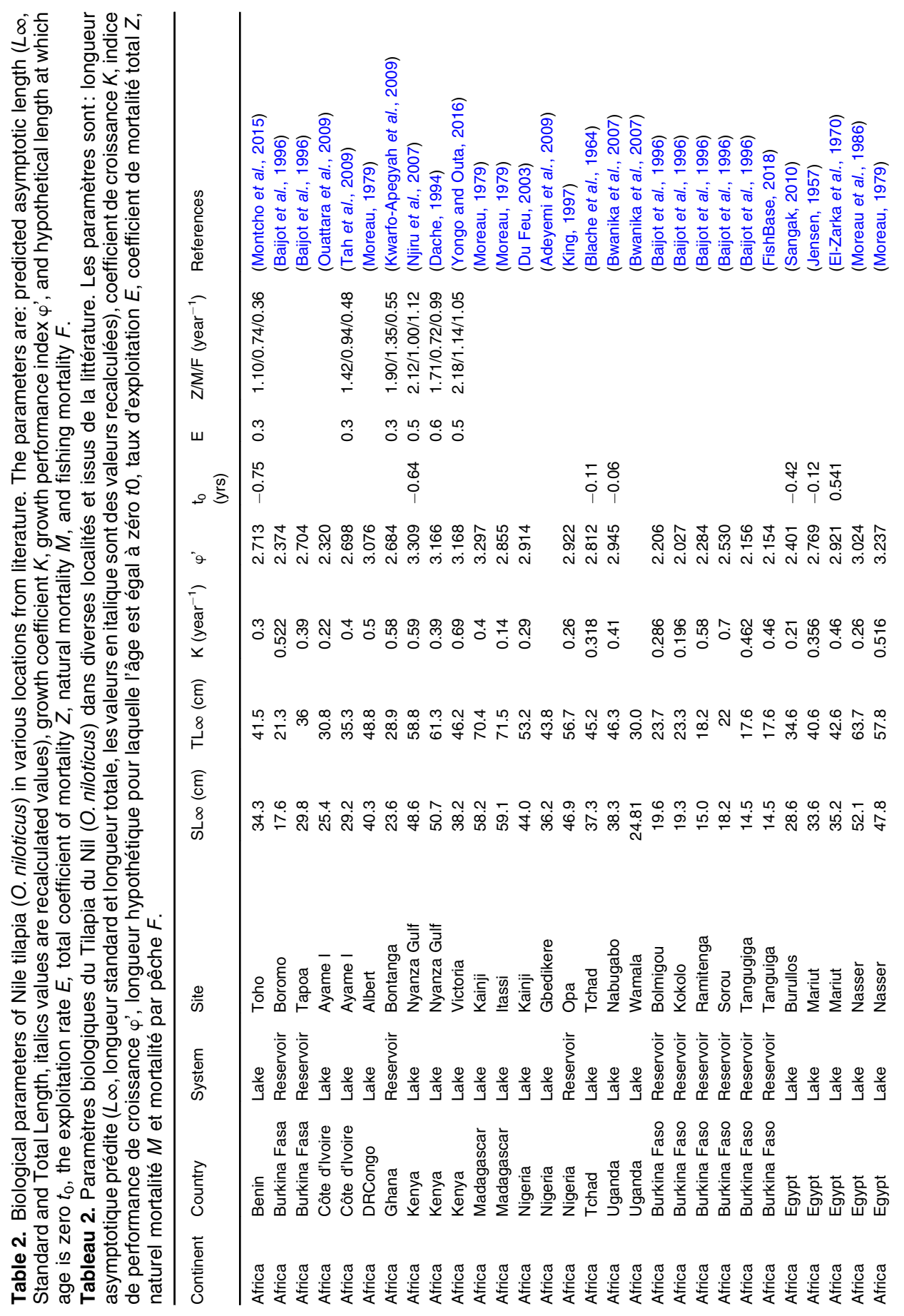




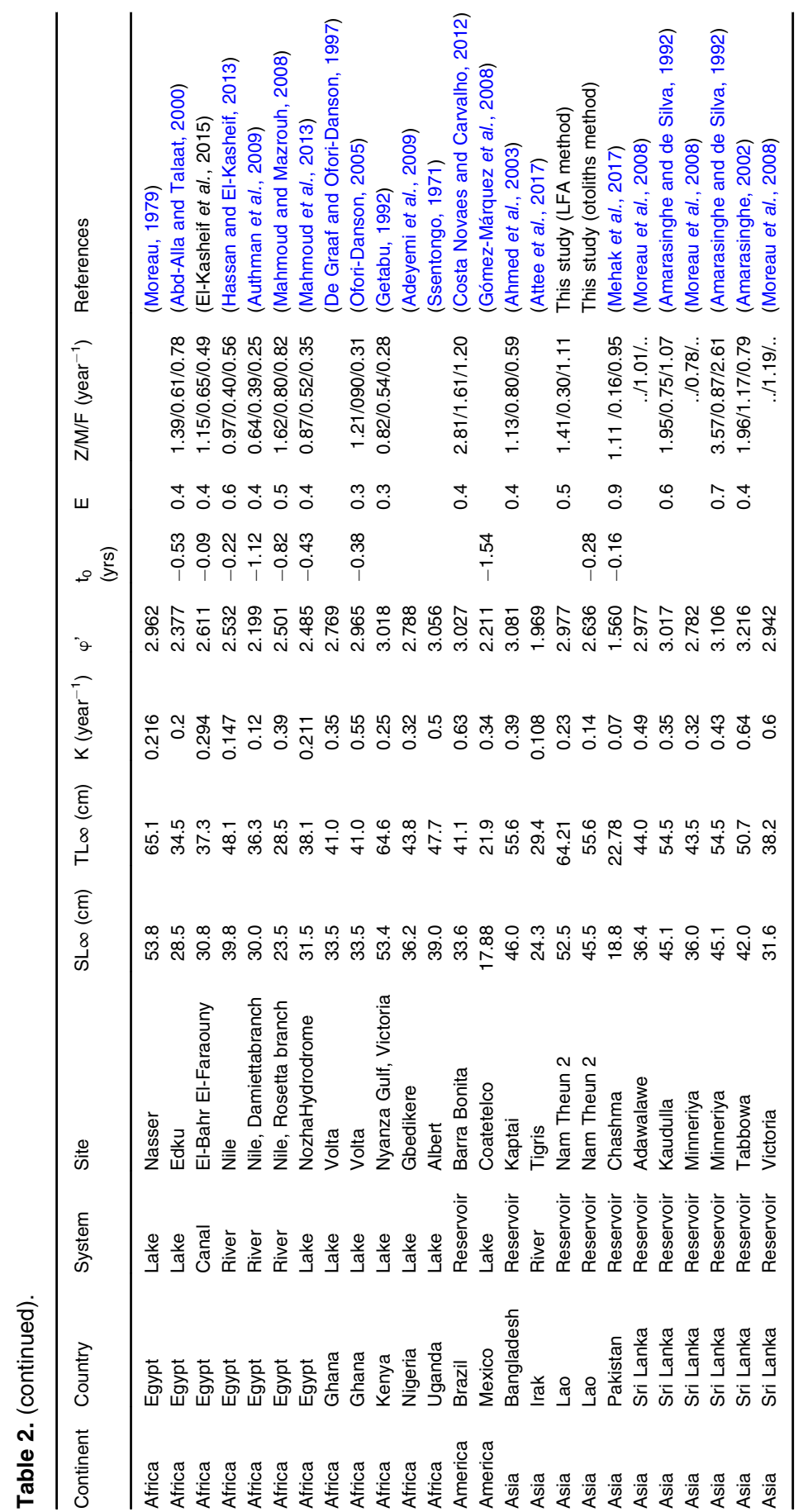



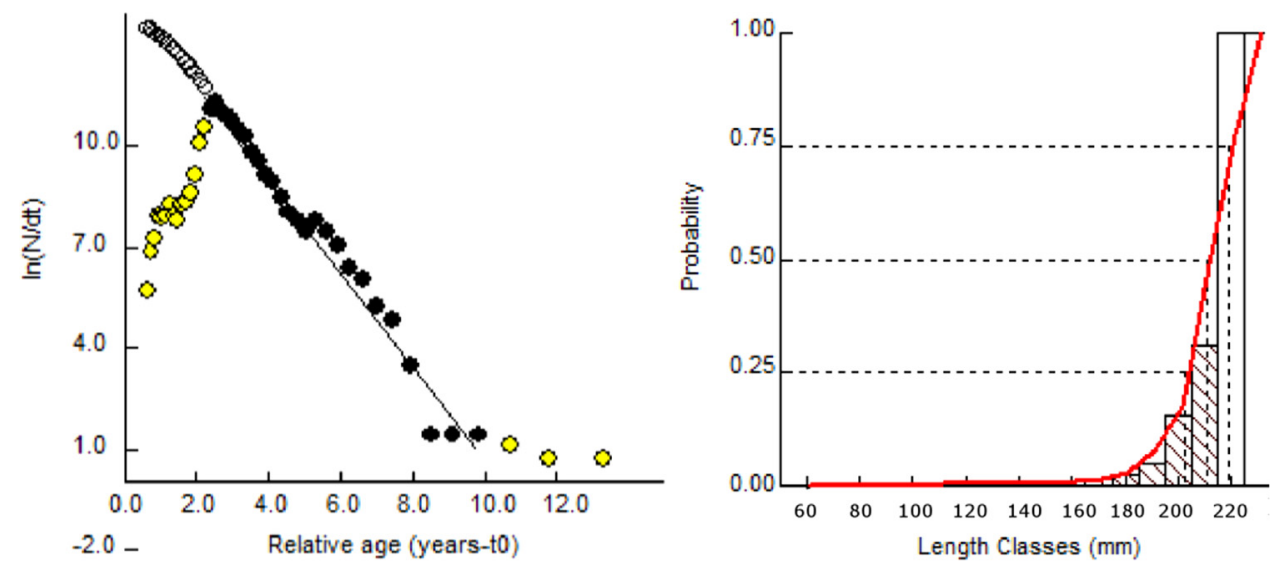

Fig. 2. Length-converted catch curve (left) of $O$. niloticus $(N=11820)$ estimating annual instantaneous total mortality $(Z)=1.41$ year $^{-1}$; Natural mortality (at $\left.26.5^{\circ} \mathrm{C}\right)(M)=0.30$ year $^{-1}$; Fishing mortality $(F)=1.11$ year $^{-1}$; Exploitation rate $(E)=0.79$. NT2 Reservoir, Lao, PDR (year 2016). Black dots of the left figure were used for $Z$ calculation (i.e. the slope) using least squares line regression $\left(R^{2}=0.98\right)$. The white dots represent the fish that would have been caught if fully recruited. The yellow dots on the left are the not fully recruited points discarded from the calculation; The ratio: expected and actual catches, gives probability of capture for each class size(right).

Fig. 2. À gauche: Courbe des captures converties en tailles d'O. niloticus $(N=11820)$ estimant la mortalité instantanée annuelle $(Z)=1,41 \mathrm{an}^{-1}$; naturelle (à $26,5^{\circ} \mathrm{C}$ ) $(M)=0,30 \mathrm{an}^{-1}$; par pêche $(F)=1,11 \mathrm{an}^{-1}$; le taux d'exploitation $(E)=0,79$ pour Nam Theun 2 en 2016 . Les ronds noirs correspondent aux données utilisées pour calculer $Z$ en utilisant la régression linéaire des moindres carrées $\left(R^{2}=0.98\right)$. Les ronds blancs représentent les poissons qui auraient été capturés si le recrutement avait été total. Les ronds jaunes sont des données correspondant à un recrutement non total et écartés du calcul. À droite: Le ratio: les captures prévues et les captures réelles donnent la probabilité de capture pour chaque taille de classe.

(Fig. 2 right). The mean length of fish at first capture $(L C)$ was equivalent to $L_{50}=210.38 \mathrm{~mm}$. Immature fish were found up to $360 \mathrm{~mm}$ but some mature fish started at $112 \mathrm{~mm}$. The proportion of mature fish was $50 \%$ for a standard length of $295 \mathrm{~mm}$ (Fig. 3). From the FiSATII virtual population analysis, the stock of the reservoir was estimated to be 165 tones with about 744000 Nile tilapias (Fig. 4). The exploitation rate was $E=0.79$. This rate was $>E_{10}=$ $0.508,>E_{50}=0.336$ and $>E_{\max }=$ 0.594 obtained by relative yield and biomass per recruit (Fig. 5). The yieldper-recruit isopleths diagram of the various length at entry for $\mathrm{O}$. niloticus into the fishery based on different values of $E$ and a constant value of $M / K=1.304$ and $L_{\infty}=525 \mathrm{~mm}$ showed the discontinued curves indicating the range producing the maximum yieldper-recruit (Fig. 6). The maximum theoretical value of relative yield-perrecruit at the meeting point of the eumetric yield curve (i.e. stable population) with the maximum sustainable yield (MSY) (so-called potential yieldper-recruit) was $Y^{\prime} / R=0.062$ with $E=0.7$ and $L c / L \infty=0.6$, that to say $L C=315 \mathrm{~mm}$. The current level of exploitation $\left(Y^{\prime} / R=0.05\right)$ is on the right side of the eumetric curve indicating potential overfishing with too many 


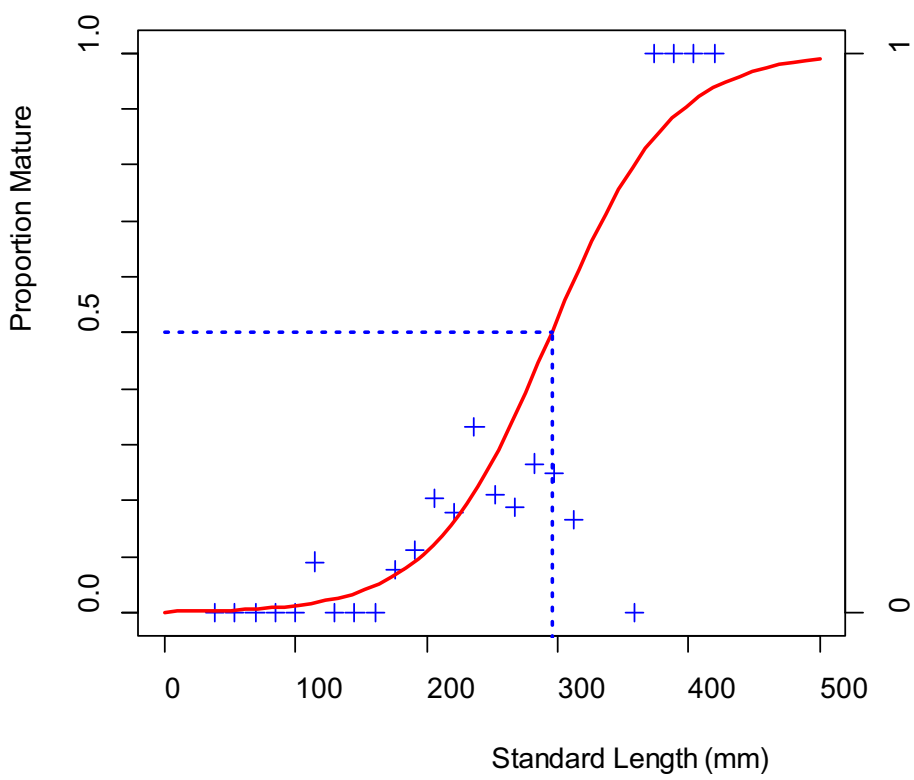

Fig. 3. Fitted logistic regression for proportion of mature Nile tilapia (O. niloticus) by standard length with $L_{50}=295 \mathrm{~mm}$ shown in blue $(\mathrm{N}=258)$ in NT2 Reservoir, Lao, PDR. The current mean length of fish at first capture was $L c=210.38 \mathrm{~mm}$.

Fig. 3. Régression logistique ajustée pour la part de Tilapia du nil (O. niloticus) mature selon la longueur standard avec $L_{50}=295 \mathrm{~mm}$ indiqué en pointillé bleu $(\mathrm{N}=258)$ pour Nam Theun 2, Laos. La longueur moyenne actuelle des poissons à la première capture $(L c)$ était de $210,38 \mathrm{~mm}$.

short fish caught (Fig. 6). Accordingly to the figures, a reduction of $E$ (moving to the left) and/or a reduction of the targeted class size (with bigger hooks and larger gill net mesh (moving to the top)), would lead to an increase in relative yield.

Value of $L_{\text {opt }}=365.9 \mathrm{~mm}$ is considered as the size of exploitation at which $O$. niloticus yield attains its maximum potential in this reservoir.

A Thompson and Bell Yield-Stock Prediction with a $L_{50}$ of $315 \mathrm{~mm}$ was compared to the current prediction with $L_{50}=210.38 \mathrm{~mm}$. For the same fishing effort of $F=1.11$, but with an increase of mesh size, the yield was near optimal capability and with $+125 \%$ than the current level. On the other hand, the biomass has more than doubled (207\%).

\subsection{Lao reservoir and worldwide $\varphi^{\prime}$ comparison}

Biological parameters of several Nile tilapia populations from various continents and hydrosystems are summarized in Table 2. The range of parameter values was wide for populations from the different ecosystems (lakes, reservoirs, rivers): $L_{\infty}=$ [SL: $\quad 145.5-591.3 \mathrm{~cm}], \quad K=[0.07-$ $0.70], \varphi \varphi^{\prime}=[1.56-3.31]$. Globally the $\varphi$ ' distribution was normal $(\mathrm{W}=0.94605, p$-value $=0.0001584)$. The average $\varphi^{\prime}$ was significantly higher in fish farms $=3.387 ; \quad \mathrm{IC}_{95}=$ [3.332-3.443] (ponds, cages, tanks, Tab. 3) than in ecosystem 2.735; $I_{95}=[2.624-2.846]$ (lakes, reservoirs, rivers) $(\mathrm{W}=173, p<0.0001)$. 


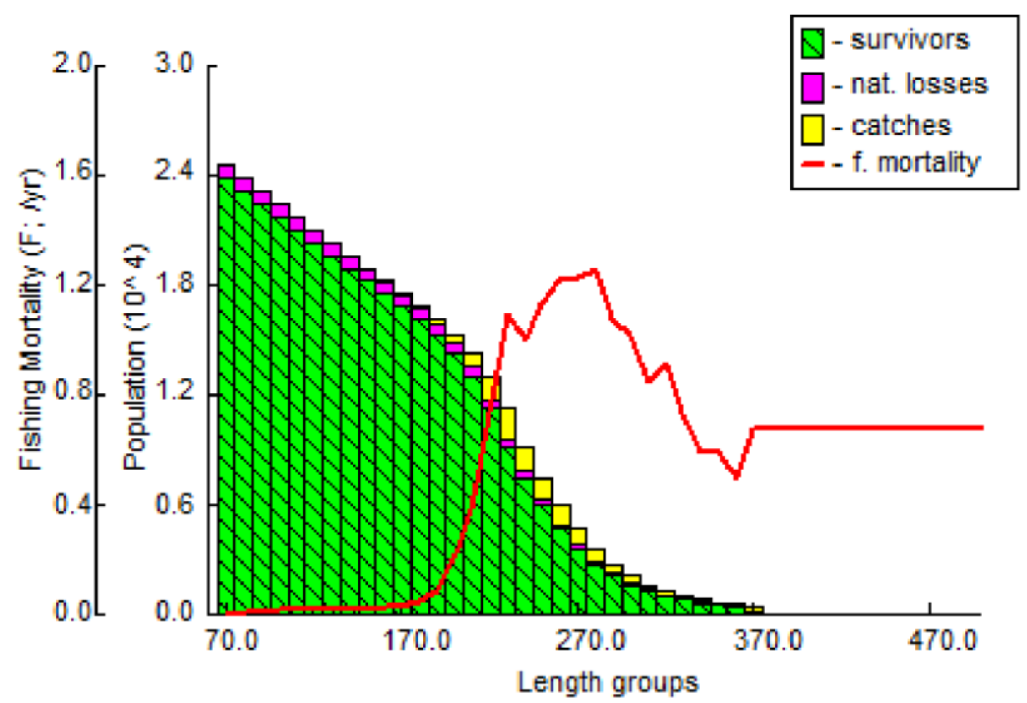

Fig. 4. Length-Structured (TL) Virtual Population Analysis (VPA) of O. niloticus (from fish landings) in NT2 Reservoir, Lao, PDR (year 2016).

Fig. 4. Analyse de la structure de taille (TL) d'une population virtuelle (VPA) d'O. niloticus (issus des débarquements de pêche) pour le réservoir de Nam Theun 2, au Laos, en 2016.

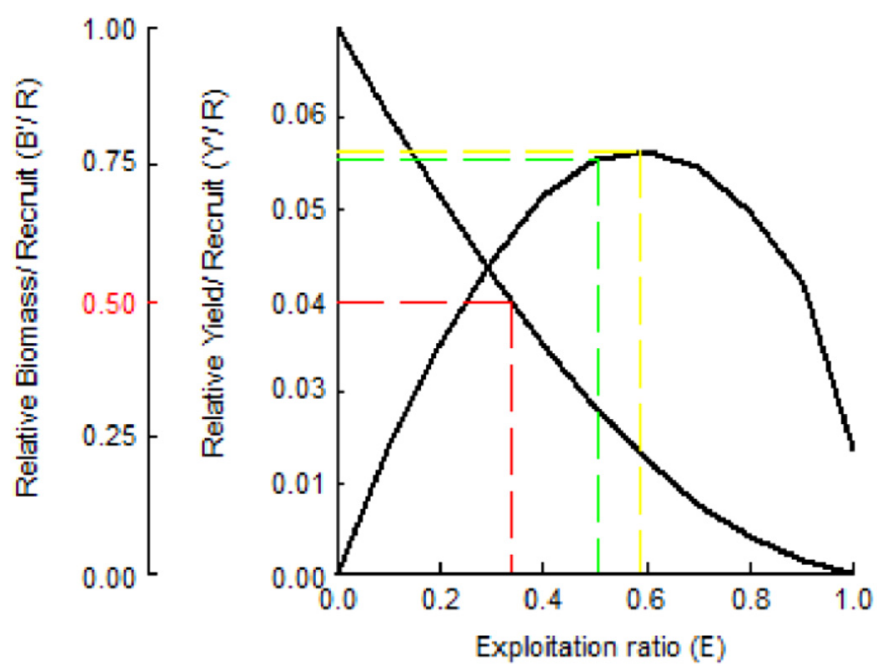

Fig. 5. Relative yield and biomass per recruit (selection ogive) of $O$. niloticus. NT2 Reservoir, Lao, PDR (year 2016). $E_{10}=0.508, E_{50}=0.336$ and $E_{\max }=0.594$ (yellow dotted line). Current $E=0.79$.

Fig. 5. Rendement relatif et biomasse par recrut (sélection ogive) d'O. niloticus pour le réservoir de Nam Theun 2, au Laos, en 2016. $E_{10}=0.508, E_{50}=0.336$ and $E_{\max }=0.594$ (ligne pointillée jaune). Actuellement $E=0,79$. 

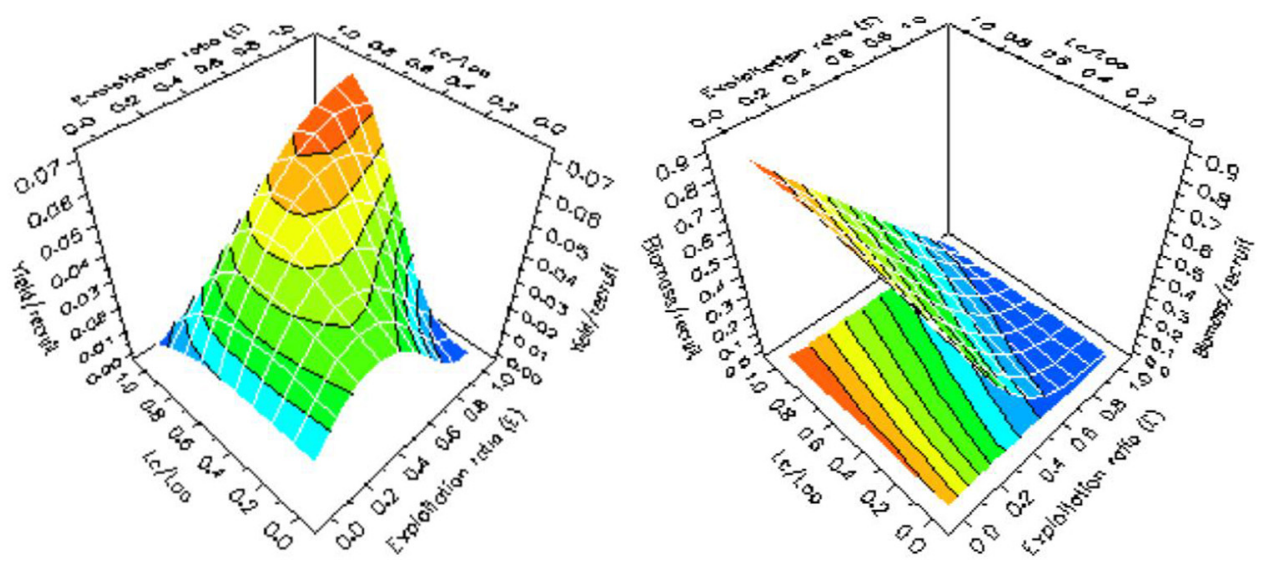

Fig. 6. 3D map of relative yield per recruit $\left(Y^{\prime} / R\right)$ (left), and relative biomass per recruit $\left(B^{\prime} / R\right)$ (right) as a function of relative size at first capture $(L C / L \infty)$ and exploitation rate $(E=F / Z$ Knife-edge with fixed $M /$ $K=1.304$. The relative yield and relative biomass per recruit increased with the vertical axis (isopleth color going to orange). For the $Y^{\prime} / R$, if the situation point is at the left of the slope (eumetric yield curve) the scenario is in underfishing situation, at the right of the slope: in overfishing. The situation in 2016 in the NT2 Reservoir for Nile tilapia was $E=79$ and $L c / L \infty=0.4$. A reduction in exploitation rate and in $L c$ with mesh size/hooks increase lead to an increase in relative yield (and overall biomass) and would be the fishing management recommendation.

Fig. 6. Représentation 3D du rendement relatif par recrue $\left(Y^{\prime} / R\right)$ (à gauche) et de la biomasse relative par recrue $\left(B^{\prime} / R\right)$ (à droite) en fonction de la taille relative à la première capture $\left(L_{c} / L_{\infty}\right)$ et du taux d'exploitation $(E=F / Z)$. Tranche d'âge avec M/K fixé à 1,304. Le rendement relatif et la biomasse relative par recrue ont augmenté avec l'axe vertical (la couleur des isoplèdes allant à l'orange). Pour le $Y^{\prime} / R$, si le point de situation est à gauche de la pente (courbe de rendement eumétrique), le scénario est en situation de sous-pêche, à droite de la pente : en sur pêche. La situation en 2016 du réservoir de Nam Theun 2 pour le tilapia du Nil était $E=79$ et $L c / L \infty=0,4$. Une réduction du taux d'exploitation et de $L c$ avec une augmentation de la taille du maillage ou recourt aux hameçons conduit à une augmentation du rendement relatif (et de la biomasse globale) et constituerait donc une recommandation de gestion pour cette pêche.

There were differences within the ecosystem and aquaculture groups (Wilcoxon rank sum tests with $P$ $<0.05$, Fig. 7). For ecosystems, the populations were not different between Africa and Asia ( $\mathrm{W}=222, p$ value $=0.797$ ).

\section{Discussion}

The NT2 Reservoir was impounded in 2008 and tends to reach an ecological equilibrium, despite significant exploitation of the ichtyo resources
(Cottet et al., 2016; Cottet and Visser, 2017). More than 2000 households rely on the O. niloticus for food. representing half of their fisheries. Consequently, knowledge on biological parameters of O. niloticus is useful for fishing management in this recent Asian reservoir and more largely for the South East Asian region. Globally, several methods exist to help fish stock management, most of them usable in various routines with FiSATII (Sparre, 1998). This study showed that the results can be slightly different between length-atage analyses versus length frequency 
Table 3. Biological parameters of Nile tilapia (O. niloticus) in aquaculture (Pauly et al., 1988). With predicted asymptotic length ( $L_{\infty}$, Standard and Total Length), growth coefficient $K$, and growth performance index $\varphi^{\prime}$.

Tableau 3. Paramètres biologiques du Tilapia du Nil (O. niloticus) en aquaculture (Pauly et al., 1988). Les paramètres sont : les longueurs asymptotiques prédite $\left(L_{\infty}\right.$ pour la longueur standard et la longueur totale), le coefficient de croissance $K$ et l'indice de performance de croissance $\varphi$ '.

\begin{tabular}{|c|c|c|c|c|c|c|}
\hline Continent & Country & Hydrosystem & $\mathrm{SL \infty}(\mathrm{cm})$ & $\mathrm{TL} \infty(\mathrm{cm})$ & $\mathrm{K}\left(\right.$ year $\left.^{-1}\right)$ & $\left(\varphi^{\prime}\right)$ \\
\hline Africa & Burkina Faso & Pond & 14.6 & 17.9 & 2.385 & 2.881 \\
\hline Africa & Burkina Faso & Pond & 22.3 & 27.3 & 0.88 & 2.816 \\
\hline Africa & Cameroon & Pond & 21.9 & 26.8 & 4.329 & 3.492 \\
\hline Africa & CAR & Tank & 15.1 & 18.5 & 7.305 & 3.396 \\
\hline Africa & CAR & Tank & 15.6 & 19.1 & 3.003 & 3.039 \\
\hline Africa & CAR & Tank & 17.3 & 21.2 & 2.997 & 3.128 \\
\hline Africa & CAR & Tank & 24.9 & 30.5 & 1.572 & 3.164 \\
\hline Africa & CAR & Tank & 25.9 & 31.7 & 1.447 & 3.162 \\
\hline Africa & Côte d'Ivoire & Cage & 19.3 & 23.6 & 4.737 & 3.421 \\
\hline Africa & Côte d'Ivoire & Cage & 23.9 & 29.2 & 1.881 & 3.206 \\
\hline Africa & Côte d'Ivoire & Pond & 19.1 & 23.4 & 6.604 & 3.557 \\
\hline Africa & Côte d'Ivoire & Pond & 23.4 & 28.6 & 3.69 & 3.480 \\
\hline Africa & Sierre Leone & Pond & 18.9 & 23.1 & 2.95 & 3.198 \\
\hline America & Puerto Rico & Pond & 15.3 & 18.7 & 5.342 & 3.272 \\
\hline America & USA & Pond & 14.2 & 17.4 & 7.291 & 3.342 \\
\hline America & USA & Pond & 20.8 & 25.4 & 6.58 & 3.629 \\
\hline America & USA & Pond & 22.5 & 27.5 & 10.458 & 3.899 \\
\hline America & USA & Pond & 22.8 & 27.9 & 4.179 & 3.512 \\
\hline America & USA & Pond & 22.8 & 27.9 & 8.028 & 3.795 \\
\hline Asia & Philippines & Cage & 12.9 & 15.8 & 13.933 & 3.540 \\
\hline Asia & Philippines & Cage & 13.2 & 16.1 & 6.544 & 3.232 \\
\hline Asia & Philippines & Cage & 15.4 & 18.8 & 7.843 & 3.444 \\
\hline Asia & Philippines & Cage & 22.4 & 27.4 & 2.915 & 3.340 \\
\hline Asia & Philippines & Pond & 12.4 & 15.2 & 7.155 & 3.216 \\
\hline Asia & Philippines & Pond & 12.7 & 15.5 & 12.348 & 3.474 \\
\hline Asia & Philippines & Pond & 13.5 & 16.5 & 9.22 & 3.400 \\
\hline Asia & Philippines & Pond & 14.9 & 18.2 & 5.685 & 3.276 \\
\hline Asia & Philippines & Pond & 15.3 & 18.7 & 10.377 & 3.560 \\
\hline Asia & Philippines & Pond & 15.6 & 19.1 & 10.742 & 3.592 \\
\hline Asia & Philippines & Pond & 16.3 & 19.9 & 9.352 & 3.570 \\
\hline Asia & Philippines & Pond & 17.4 & 21.3 & 10.631 & 3.683 \\
\hline Asia & Philippines & Pond & 20.6 & 25.2 & 5.409 & 3.536 \\
\hline Asia & Philippines & Pond & 23.6 & 28.9 & 6.879 & 3.758 \\
\hline Asia & Philippines & Pond & 23.8 & 29.1 & 3.854 & 3.514 \\
\hline Asia & Thailand & Pond & 12.9 & 15.8 & 5.476 & 3.134 \\
\hline Asia & Thailand & Pond & 13.7 & 16.8 & 9.712 & 3.436 \\
\hline Asia & Thailand & Pond & 15.8 & 19.3 & 8.889 & 3.521 \\
\hline Asia & Thailand & Pond & 16.6 & 20.3 & 10.942 & 3.654 \\
\hline Asia & Thailand & Pond & 16.9 & 20.7 & 7.651 & 3.514 \\
\hline Asia & Thailand & Tank & 10.3 & 12.6 & 19.644 & 3.494 \\
\hline Asia & Thailand & Tank & 10.7 & 13.1 & 7.263 & 3.095 \\
\hline Asia & Thailand & Tank & 11.1 & 13.6 & 13 & 3.379 \\
\hline Asia & Thailand & Tank & 11.4 & 13.9 & 6.423 & 3.096 \\
\hline Asia & Thailand & Tank & 11.8 & 14.4 & 4.15 & 2.937 \\
\hline Asia & Thailand & Tank & 12 & 14.7 & 9.871 & 3.328 \\
\hline Asia & Thailand & Tank & 12.3 & 15.0 & 6.534 & 3.170 \\
\hline Asia & Thailand & Tank & 13.3 & 16.3 & 7.093 & 3.273 \\
\hline Asia & Thailand & Tank & 13.3 & 16.3 & 7.628 & 3.305 \\
\hline Asia & Thailand & Tank & 13.7 & 16.8 & 4.75 & 3.125 \\
\hline
\end{tabular}


Table 3. (continued).

\begin{tabular}{lllllll}
\hline Continent & Country & Hydrosystem & SL $\infty(\mathrm{cm})$ & TL $\infty(\mathrm{cm})$ & K (year $\left.{ }^{-1}\right)$ & $\left(\varphi^{\prime}\right)$ \\
\hline Asia & Thailand & Tank & 15.7 & 19.2 & 7.157 & 3.421 \\
Asia & Thailand & Tank & 15.8 & 19.3 & 7.109 & 3.424 \\
Asia & Thailand & Tank & 18.3 & 22.4 & 5.881 & 3.469 \\
Europe & Belgium & Pond & 19 & 23.2 & 4.789 & 3.413 \\
Europe & Belgium & Pond & 21.5 & 26.3 & 2.265 & 3.195 \\
Europe & Belgium & Pond & 22.2 & 27.2 & 4.271 & 3.498 \\
Europe & Belgium & Pond & 23.1 & 28.3 & 2.54 & 3.307 \\
Europe & Belgium & Pond & 40.8 & 49.9 & 0.716 & 3.251 \\
Europe & Belgium & Tank & 13.2 & 16.1 & 13.207 & 3.537 \\
Europe & Belgium & Tank & 17.3 & 21.2 & 12.654 & 3.753 \\
Europe & Belgium & Tank & 18.6 & 22.7 & 4.221 & 3.339 \\
Europe & Belgium & Tank & 18.9 & 23.1 & 10.665 & 3.756 \\
Europe & Belgium & Tank & 22.5 & 27.5 & 2.984 & 3.354 \\
Europe & Belgium & Tank & 23.3 & 28.5 & 5.419 & 3.643 \\
Europe & Belgium & Tank & 29.9 & 36.6 & 2.076 & 3.443 \\
\hline
\end{tabular}

distribution growth analyses, with the same fish stock, sampled at the same year. The sampling method can affect biological parameters results and thus potentially changing other parameters such as mortality $M$ or even Beverton and Holt $Y / R$ analyses (Knife-edge) which is calculated mainly with $K$ and Lo.

Otolith readings are a robust method but the lower sample size of this study prevented recording fish of extreme large sizes (for $L_{\infty}$ determination). For instance, a 8 years old female was aged in this study, which is the oldest age published for Nile tilapia in the literature (FishBase, 2018), but had a SL of only $280 \mathrm{~mm}$ (in the literature). Thus indicating a probable margin of more growing. The $L_{\infty}$ is $=454$ versus $525 \mathrm{~mm}$ for the length at age and the length frequency analyses respectively. However, $K$ was 0.14 for males and for all sex pooled, but 0.23 for females only, equal to 0.23 found from the length frequency analyses. These results complicated the inter and intra-population comparisons regularly found in literature (Tab. 2). Furthermore, site comparisons have to be cautious because some parameters based on experimental fishing with are from low sample size or short period of sampling. However, in this study case, insufficient sampling showed irrelevant results for this type of analysis despite costly sampling efforts (24 nights, 3 staff/boat for this protocol). The main conclusion for fish landings or experimental sampling choice of protocol is that bulky data based on fishermen are more robust even if the catches are not standardized with a fishing protocol, because of the high data number reaching representativeness. Furthermore, this method is logistically easier. This method is thus recommended according to the scientific questions and needs. This example recalls best practices for using the ELEFAN approach (Brey and Pauly, 1986; Pauly and Morgan, 1987; Taylor and Mildenberger, 2017): the length frequency data should (i) contain relatively high counts that are representative of the length distribution 


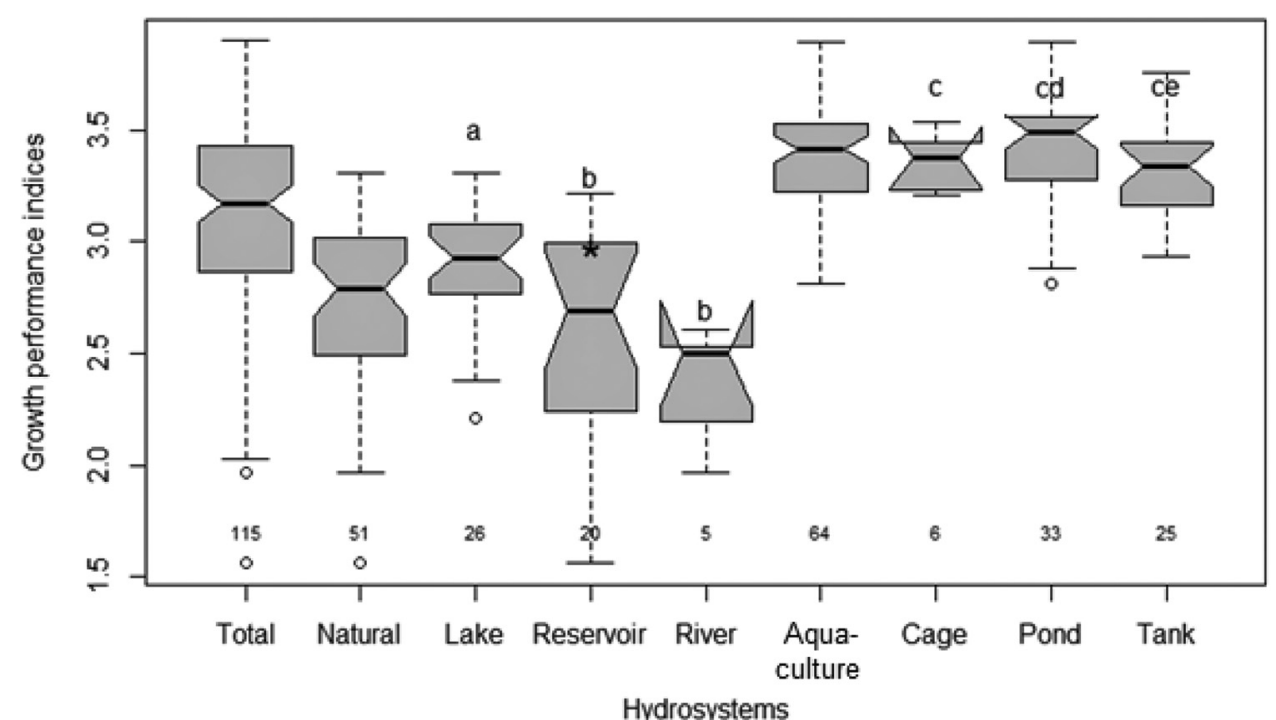

Fig. 7. The growth performance indices $\left(\varphi^{\prime}\right)$ of Nile tilapia (O. niloticus) in various hydrosystems. Groups significantly different are represented by letters (Wilcoxon rank sum tests, $P<0.05$ ). Below each box, the effective of bibliographic resources indicates the number of used. $\mathrm{N}$ are indicated below the boxes. The star represents the NT2 Reservoir, Lao PDR.

Fig. 7. Les indices de performance de croissance ( $\left.\varphi^{\prime}\right)$ du Tilapia du Nil (O. niloticus) dans divers hydrosystèmes. Les groupes significativement différents sont identifiés par une lettre (test de Wilcoxon, $P<0,05$. L'étoile représente Nam Theun 2 au Laos.

of the population or catches; (ii) be sampled at regular intervals throughout the year with the same sampling effort and (iii) cover a substantial degree of small class sizes, as their relatively higher numbers and faster growth will aid in the fitting of the growth curve. A general rule-of-thumb could be that the smallest class size should start at least $25 \%$ of $L \infty$. Our experimental fishing study case failed for condition (i).

This finding highlights the need to compare the biological parameters of a fish population with cautious. Indeed, various methods seem to provide slightly different results. The species range for $K$ is [0.14-0.41 years ${ }^{-1}$ ] on Fishbase (FishBase, 2018), but seems to be wider on Table 1. $\varphi$ ' can be used to compare populations as long as similar units and definitions are used (see routine's requests in FiSAT II) and cautions have to be taken for ichthyologists for comparisons using external $\varphi$ ' data. However, the meaningful low growth performance indices $\varphi$ ' can be noticed for populations suffering challenging environment (e.g. oligotrophic waters, low temperature, etc. and high $\varphi$ ' for population under relatively severe predation/fishing pressure (Amarasinghe, 2002; Njiru et al., 2007; Moreau et al., 2008; Costa Novaes and Carvalho, 2012; Yongo and Outa, 2016).

Based on these data, O. niloticus of NT2 Reservoir seems to be overfished. The current $E$ is 0.79 which is superior to $E_{\max }=0.594$, leading to an over 
exploitation of the population with reduced biomass, density and ultimately to reduced yield per recruit relatively to its optimal potential ( 0.05 instead of 0.062 ). Reducing the fishing mortality from 1.11 to 0.45 would increase the population biomass by $195 \%$ and thus the yield by $114 \%$. Furthermore, the fish start to be caught at $210 \mathrm{~mm}$ through the current gillnet mesh size. Many of these fish did not reproduced more than once or are even immature and will never participate to the population renewal. Using bigger mesh size would lead to an increase in the yield. The social, economic and technical implications of changes in current fishing practices must not be overlooked. A dedicated feasibility study should probably be done and a pedagogic and technical support should be provided to local populations. Other ecological effects of the O.niloticus deserve to be studied.

\section{ACKNOWLEDGMENTS}

This work was funded by the EDF$\mathrm{CIH}$ (Centre d'Ingénierie Hydraulique France), by the Nam Theun 2 Power Company (NTPC - Lao PDR) through a project led by UMR CARRTEL (INRAUSMB, France). The fieldwork was performed thanks to the Nam Theun 2 Power Company, whose shareholders are Électricité de France, Lao Holding State Enterprise and Electricity Generating Public Company Limited of Thailand. The authors would like to thank all villagers who participated in the fish landing survey, the staff of the NTPC, especially the Environment Department, including Khampong
THAN-Onkeo, Sengthien Vongvilaysuk, Seesouk XAYABOUNPHENG, and Sengsavanh PHOMPHILATH, for their technical and human support in the laboratory in Lao PDR. We would also like to thank Michel COLON and Jean-Christophe HUSTACHE of the UMR CARRTEL for their help in the field and the laboratory in Lao PDR.

\section{REFERENCES}

Abd-Alla A. \& Talaat, K.M., 2000. Growth and dynamics of tilapias in Edku Lake, Egypt, Bull. Nat. Inst. Oceanogr. Fish. 26: 183-196.

Adeyemi S.O., Bankole N.O., Adikwu I.A. \& Akombu P.M., 2009. Age, growth and mortality of some commercially important fish species in Gbedikere Lake, Kogi State Nigeria, Int. J. Lakes Rivers 2 (1): 45-51.

Ahmed K.K.U., Amin S.M.N., Haldar G.C. \& Dewan S., 2003. Population dynamics and stock assessment of Oreochromis niloticus (Linnaeus) in the Kaptai Reservoir, Bangladesh, Indian. J. Fish. 50 (1): 47-52.

Amarasinghe U.S., 2002. The fishery and population dynamics of Oreochromismossambicus and Oreochromis niloticus (Osteichthyes, Cichlidae) in a shallow irrigation reservoir in Sri Lanka, Asian Fish. Sci. 15: 7-20.

Amarasinghe U.S., \& de Silva S.S., 1992. Population dynamics of Oreochromis mossambicus and $\mathrm{O}$. niloticus (Cichlidae) in two reservoirs in Sri Lanka, Asian Fish. Sci. 5: 37-61.

Attee R.S., Alheni A., Jassem K., Abd A. \& Khalifa S.Z., 2017. Description of the growth of Nile tilapia (Linnaeus, 1758) Oreochromis niloticus in the Tigris River south of Baghdad, Int. J. ChemTech Res. 10(9): 9. 
Authman M.M.N., El-Kasheif M.A. \& Shalloof K.A.S., 2009. Evaluation and management of the fisheries of Tilapia species in Damietta Branch of the River Nile, Egypt, World J. Fish. Mar. Sci. 1: 167-184.

Baijot E., Barry I., Bouda S., Kabore K.H. \& Traore A.C., 1996. Comparative growth of Oreochromis niloticus and Sarotherodon galilaeus in small artificial lakes in Burkina Faso and the larger lakes of Africa. In: The third International Symposium on Tilapia Aquaculture, ICLARM Conf. Proc., pp. 28-32.

Beverton R. \& Holt S., 1966. Manual of methods for fish stock assessment-Part 2-tables of yield functions, FAO Fish. Tech. Paper 38: 67.

Beverton R.J.H., 1992. Patterns of reproductive strategy parameters in some marine teleost fishes, J. Fish Biol. 41: 137-160.

Blache J., Milton F., Stauch A., Iltis A. \& Loubens G., 1964. Les poissons des bassins du Tchad et du bassin adjacent du Mayo Kebbi : étude systématique et biologique.

Brey T. \& Pauly D., 1986. Electronic length frequency analysis: a revised and expanded user's guide to ELEFAN 0, 1 and 2.

Bwanika G.N., Murie D.J. \& Chapman L.J., 2007. Comparative age and growth of Nile tilapia (Oreochromis niloticus L.) in lakes Nabugabo and Wamala, Uganda, Hydrobiologia 589(1): 287-301.

$\mathrm{CABI}, 2018$. Oreochromis niloticus. Invasive Species Compendium. Wallingford, UK: CAB International. www. cabi.org/isc.

Canonico G.C., Arthington A., McCrary J.K. \& Thieme M.L., 2005. The effects of introduced tilapias on native biodiversity, Aquat. Conserv.: Mar. Freshw. Ecosyst. 15(5): 463-483.
Casal C.M.V., 2006. Global documentation of fish introductions: the growing crisis and recommendations for action, Biol. Invasions 8(1): 3-11.

Costa Novaes J.L., \& Carvalho E.D., 2012. Reproduction, food dynamics and exploitation level of Oreochromis niloticus (Perciformes: Cichlidae) from artisanal fisheries in Barra Bonita Reservoir, Brazil, Revista de Biol. Trop. 60(2): 721-734.

Cottet M. \& Visser T.A.M., 2017. Fish catch and fishing practices in the Nam Theun 2 Reservoir and watershed (Lao PDR), Lakes Reserv.: Res. Manag.

Cottet M., Descloux S., Guédant P., Cerdan P. \& Vigouroux R., 2016. Fish population dynamic in the newly impounded Nam Theun 2 Reservoir (Lao PDR), Hydroécologie Appliquée 19: 321-355.

Cucherousset J. \& Olden J.D., 2011. Ecological impacts of nonnative freshwater fishes, Fisheries 36(5): 215-230.

Dache S.A.O., Observations on the fisheries, growth and mortality of Oreochromis niloticus (tilapia) in Nyanza Gulf of Lake Victoria. In: Proceedings of the second EEC regional seminar on the recent trends of research on Lake Victoria fisheries, ICIPE Press, Kenya, 1994, pp. 56-65.

De Graaf G.J. \& Ofori-Danson P.K., 1997. Catch and fish stock assessment in stratum VII of Lake Volta. FAO.

De Silva S.S., Subasinghr R.P., Bartley D. M. \& Lowther A., 2004. Tilapias as alien aquatics in Asia and the Pacific: a review. Rome: FAO.

Descloux S., Guedant P., Phommachanh D. \& Luthi R., 2016. Main features of the Nam Theun 2 hydroelectric project (Lao PDR) and the associated environmental monitoring programmes, Hydroécologie Appliquée 19: 5-25.

Du Feu T.A., 2003. Population parameters for the six commercial species in Lake Kainji, Nigeria using length frequency 
data sampled from artisanal fish catches, ACP-UE Fish. Res. Rep. 14: 15.

El-Zarka S., Shaheen A.H. \& Aleem A.A., 1970. Tilapia fisheries in Lake Mariut. Age and growth of Tilapia nilotica (L.) in the Lake, Bull. Inst. Oceanogr. Fish. Egypt 1: 149-182.

FAO, 2009. Oreochromis niloticus. In: Cultured aquatic species fact sheets. CD-ROM. multilingual). http://www.fao. org/tempref/FI/CDrom/aquaculture/ (Accessed: 20/07/2018).

Figueredo C.C. \& Giani A., 2005. Ecological interactions between Nile tilapia (Oreochromis niloticus L.) and the phytoplanktonic community of the Furnas Reservoir (Brazil), Freshw. Biol. 50 (8): 1391-1403.

FishBase, 2018. FishBase. World Wide Web electronic publication. www.fish base.org (Accessed: 24/07/2018).

Froese R., Stern-Pirlot A., Winker H. \& Gascuel D., 2008. Size matters: how single-species management can contribute to ecosystem-based fisheries management, Fish. Res. 92(2-3): 231-241.

Garaway C., Lorenzen K. \& Chamsingh B., 2000. Developing fisheries enhancement in small waterbodies: lessons from Lao PDR and Northeast Thailand. In: Reservoir and culture-based fisheries: Biology and management. Bangkok, Thailande: ACIAR, pp. 227-234.

Gayanilo F.C., Sparre P. \& Pauly D., 2005. FAO-ICLARM stock assessment tools II: Revised version: User's guide. FAO Computerized Information Series: Fisheries. Rome, FAO: Food and Agriculture Organization of the United Nations.

Getabu A., 1992. Growth parameters and total mortality in Oreochromis niloticus (Linnaeus) from Nyanza Gulf, Lake Victoria, Hydrobiologia 232(1): 91-97.
Gómez-Márquez J.L., Peña-Mendoza B., Salgado-Ugarte I.H. \& Arredondo-Figueroa J.L., 2008. Age and growth of the tilapia, Oreochromis niloticus (Perciformes: Cichlidae) from a tropical shallow lake in Mexico, Revista de Biol. Trop. 56(2): 875-884.

Hassan A.A. \& El-Kasheif M.A., 2013. Age growth and mortality of the cichlid fish Oreochromis Niloticus (L.) from the River Nile at Beni Suef Governorate Egypt, Egypt. J. Aquat. Biol. Fish. 287 (1828): 1-24.

Ishikawa T., Shimose T. \& Tachihara K., 2013. Life history of an invasive and unexploited population of Nile tilapia (Oreochromis niloticus) and geographical variation across its native and non-native ranges, Environ. Biol. Fish. 96: 603-616.

Jensen K.W., 1957. Determination of age and growth of Tilapia nilotica L., T. galilaea Art., T. zillii Ger., and Lates niloticus C. et $V$. by means of their scales, $K$. Nor. Vidensk. Selsk. Forh. 30: 150-157.

King R.P., 1997. Growth performance of Nigerian fish stocks, Naga, ICLARM Q. 20(2): 31-35.

Kwarfo-Apegyah K., Ofori-Danson P.K. \& Nunoo F.K.E., 2009. Exploitation rates and management implications for the fisheries of Bontanga Reservoir in the Northern region of Ghana, West Afr. J. Appl. Ecol. 14(1).

Mahmoud H.H. \& Mazrouh M.M., 2008. Biology and fisheries management of tilapia species in Rosetta branch of the Nile River, Egypt, Egypt. J. Aquat. Res. 34(3): 272-285.

Mahmoud H.H., Ezzat A.A., Ali T.E.-S. \& El Samman A., 2013. Fisheries management of cichlid fishes in Nozha Hydrodrome, Alexandria, Egypt, Egypt. J. Aquat. Res. 39(4): 283-289. 
Mehak A., Mu Y., Mohsin M., Noman M. \& Nazir K., 2017. Population dynamics of Nile Tilapia (Oreochromis niloticus) at Chashma Barrage, Pakistan, Indian J. Geo-Mari. Sci. 46(01): 206-210.

Montcho S.A., Agadjihouèdé H., Montchowui E., Lalèyè P.A. \& Moreau J., 2015. Population parameters of Oreochromis niloticus (Cichlidae) recently introduced in lake Toho (Benin, West Africa), Int. J. Fish. Aquat. Stud. 2(3).

Moreau J., 1979. Biologie et évolution des peuplements de Cichlides (Pisces) introduits dans les lacs malgaches d'altitude. Thèse doctorat d'État, Institut National Polytechnique de Toulouse, Toulouse, France.

Moreau J., Bambino C. \& Pauly D., 1986. Indices of overall growth performance of 100 tilapia (Cichlidae) populations [Africa; Asia]. In: The First Asian Fisheries Forum, Asian Fisheries Society, Manila, Philippines, pp. 201-206.

Moreau J., Amarasinghe U. \& Ajith Kurama P., 2008. Population dynamics of nonexploited and under-exploited fish species in three reservoirs of Sri Lanka. In: Aquatic ecosystems and development: Comparative asian perspectives, biology of inland waters. Leiden: Backhuys Publishers.

Njiru M., Okeyo-Owuor J.B., Muchiri M., Cowx I.G. \& Van der Knaap M., 2007. Changes in population characteristics and diet of Nile tilapia Oreochromis niloticus (L.) from Nyanza Gulf of Lake Victoria, Kenya: what are the management options?, Aquat. Ecosyst. Health Manag. 10(4): 434-442.

Ofori-Danson P.K., 2005. An assessment of the purse-seine (winch-net) fishery in Lake Volta, Ghana, Lakes Reserv.: Res. Manag. 10(3): 191-197.

Ouattara N.I., Iftime A. \& Mester L.E., 2009. Age et croissance de deux espèces de cichlidae (pisces): Oreochromis niloticus (Linnaeus, 1758) et Sarotherodon melanotheron rüppell, 1852 du lac de barrage d'Ayamé (Côte d'Ivoire, Afrique de l'ouest), Travaux du muséum national d'histoire naturelle « Grigore Antipa » 52: 313-324.

Pauly D., 1980. On the interrelationships between natural mortality, growth parameters, and mean environmental temperature in 175 fish stocks, ICES J. Mar. Sci. 39(2): 175-192.

Pauly D., 1983. Length-converted catch curves: a powerful tool for fisheries research in the tropics (part 1), Fishbyte 1(2) 9-13.

Pauly, D. \& Morgan, G.R., 1987. Lengthbased methods in fisheries research. In: ICLARM Conference Proceedings 13, ICLARM, Manila, Philippines, and Kuwait Institute for Scientific Research, Safat, Kuwait.

Pauly, D. \& Munro J.L., 1984. Once more on the comparison of growth in fish and invertebrates, Fishbyte (FAO Philippines) 2(1): 21.

Pauly D., Moreau J. \& Prein M., A comparison of overall growth performance of tilapia in open waters and aquaculture. In: The Second International Symposium on Tilapia in Aquaculture, ICLARM Conference Proceedings, ICLARM Contribution 322, ICLARM, Manilla, Philippines, 1988, pp. 469-479.

Pullin R.S., Palmares M.L., Casal C.V., Dey M.M. \& Pauly D., Environmental impacts of tilapias. In: Proceedings of the Fourth International Symposium on Tilapia in Aquaculture, USA, Fitzsimmons, K.M., 1997, pp. 554-572.

R Development Core Team, 2011. R: A language and environment for statistical computing. Available from http://www. R-project.org. 
Sangak Y.K., 2010. Distribution and abundance of fishes with special reference to Tilapia species in Lake Burullos. Ph.D., Faculty of Science, Zagazig University, Egypt.

Sparre P., 1998. Introduction to tropical fish stock assessment. Part 1. Manual, FAO Fish. Tech. Paper 306, 1-407.

Ssentongo G.W. 1971. Yield equations and indices for tropical freshwater fish populations. Master Sc., University of British Columbia.

Tah L., Da Costa K.S., Douba V.N., Kouassi J.N. \& Moreau J., 2009. Preliminary assessment of major Tilapiine fishes exploited by artisanal gillnet fishery in Lake Ayame I (Bia Basin, Cote d'Ivoire), J. Fish. Int. 4(4): 83-90.

Taylor M.H. \& Mildenberger T.K., 2017. Extending electronic length frequency analysis in R, Fish. Manag. Ecol. 24(4): 330-338.

Tessier A., Guillard J., Chanudet V. \& Cottet M., 2017. Length-weight relationships of eight Asian freshwater fish species in Nam Theun 2 Reservoir (Laos PDR), J. Appl. Ichthyol. 33(3): 658-660.

Thompson W.F. \& Bell F.H., 1934. Biological statistics of the pacific halibut fishery 2 .
Effect of changes in intensity upon total yield and yield per unit of gear, Rep. Int. Fish Commission 8: 49.

Weyl O.L.F., 2008. Rapid invasion of a subtropical lake fishery in central Mozambique by Nile tilapia, Oreochromis niloticus (Pisces: Cichlidae), Aquat. Conserv.: Mar. Freshw. Ecosyst. 18(6): 839-851.

Yongo E. \& Outa N., 2016. Growth and population parameters of Nile tilapia, Oreochromis niloticus (L.) in the open waters of Lake Victoria, Kenya, Lakes Reserv.: Res. Manag. 21(4): 375-379.

Zambrano L., Martínez-Meyer E., Menezes N. \& Peterson A.T., 2006. Invasive potential of common carp (Cyprinus carpio) and Nile tilapia (Oreochromis niloticus) in American freshwater systems, Can. J. Fish. Aquat. Sci. 63(9): 1903-1910.

Zengeya T.A., Robertson M.P., Booth A.J. \& Chimimba C.T., 2013. Ecological niche modeling of the invasive potential of Nile tilapia Oreochromis niloticus in African river systems: concerns and implications for the conservation of indigenous congenerics, Biol. Invasions 15(7): 1507-1521. 